\title{
Analysis of Factors Influencing Marketing Channel Choices by Smallholder Farmers: A Case Study of Paddy Product in Wet and Dry Season of Prey Veng Province, Cambodia
}

\author{
Rachana Chiv ${ }^{1,2}$, Fengying $\mathrm{Nie}^{1}$, Shu $\mathrm{Wu}^{1} \&$ Sokea Tum ${ }^{3}$ \\ ${ }^{1}$ Agricultural Information Institute, Chinese Academy of Agricultural Sciences, Haidian, Beijing, China \\ ${ }^{2}$ Agricultural Information and Documentation Centre, Ministry of Agriculture Forestry and Fisheries, Cambodia \\ ${ }^{3}$ Department of Agriculture, Regional Polytechnic Institute Techo Sen Battambang, Ministry of Labour and \\ Vocational Training, Cambodia \\ Correspondence: Rachana Chiv, Agricultural Information Institute of Chinese Academy of Agricultural Sciences, \\ Haidian, Beijing, China. E-mail: rachana_chiv@yahoo.com
}

Received: April 30, 2020

doi:10.5539/jsd.v13n4p15
Accepted: June 4, $2020 \quad$ Online Published: July 162020

URL: https://doi.org/10.5539/jsd.v13n4p15

\begin{abstract}
This study analyzes factors influencing marketing channels that were chosen by paddy smallholder farmers in the wet and dry season. The aims focused on determining the factors influence marketing channel choices to be able to reveal out the need for smallholder farmers to increase their productions and investments to formulate policies to enhance them such as increasing revenue, poverty alleviation, food security, and sustainable development. The primary data was collected through structured and semi-structured interviews with 216 smallholder farmers cultivated in both seasons, 12 collectors, 12 traders, 12 millers, 6 wholesalers, and 6 retailers by analyzed with Multinomial Logit. Results revealed that socio-economic, institutional, and marketing factors were different statistically significant influence into marketing channel choices in both seasons. These findings relate to factors that need to resolve and stimulate smallholder farmers to choose the right marketing channels by suggestion to policymakers. The outcomes of policies aim to stimulate and encourage extension office to support, sharing experiences, and knowledge to smallholder farmers who older, low experiences, and low educations. To improve extension services by the focus on telecommunications, storage facilities, and rural infrastructures. Moreover, urge smallholder farmers to market participation, and enhance market competitions. Finally, the policymakers should work efforts to improve and enhance the ongoing investments in the water supporting such as small, medium, large irrigation systems, and so forth for reducing the constraints.
\end{abstract}

Keywords: marketing channels, Multinomial Logit, smallholder farmers, paddy, wet and dry season in Cambodia

\section{Introduction}

The marketing of agriculture products plays an important role in achieving the common aims of food security, poverty reduction, and sustainable agriculture, especially among smallholder farmers in the rural area (Kyaw et al., 2018). Baines et al. (2017) found that a marketing channel might be set as an organization or agency that implements an activity linking producers with consumers to make a product or service available. It was divided into two categories such as a direct and indirect marketing channel (MacInnis, 2004; Brumfield, 2005; LeRoux, 2010; Seemanon et al., 2015). A direct marketing channel was a channel that a trader might sell its products to consumers directly or end-users (LeRoux, 2010). Whereas, an indirect marketing channel was a channel that was used to run business and selling the products through intermediaries such as retailers, wholesalers, cooperatives, traders, agents/brokers, distributors, and so forth (MacInnis, 2004; Brumfield, 2005; LeRoux, 2010). In the marketing channel, producers were challenged with the predicament of selecting between sales directly to consumers at a higher price or sale indirect marketing channels at a relatively low price in the product large volumes (LeRoux, 2010; Seemanon et al., 2015). Fafchamps and Hill (2005) revealed the evidence of smallholder farmers got crop's price differences between the channels for selling their products to the market and had implications for the welfare effect of commercialization. Ouma et al. (2010) found that mostly smallholder farmers who lived in rural areas face low reliable market information and partners exchange information 
effectively. Mmbando et al. (2016) revealed that some of the smallholder farmers had constraints with insufficient marketing price information, association or group, poor road quality to the market, cooperation and communication with the buyer, bargaining power, access to credit, extension service, and low education. Soe et al. (2015) revealed the constraints of smallholder farmers sold their products to indirect marketing channels were large of products, insufficient market information, poor road condition, lack of storage facility, and own transportation facility. Cazzuffi \& McKay (2012) revealed that selling to indirect marketing channels might be more convenient for smallholder farmers but limited buyers and low competition. Moreover, they need to sell hurry after harvested in aimed to pay back the loan that was used in their productions and household expenses (Soe et al., 2015) that might also urge to use indirect marketing channels. In addition, some of them might face their type of seed due to market needed. All those constraints were factors that might reduce their profits. Thus, it was necessary to take steps to stimulate the economic activities of smallholder farmers so that they might improve their competitiveness and profits in the markets. Therefore, the study of marketing channels was chosen by paddy smallholder farmers in Cambodia very important and useful to farmers, researchers, stakeholder effective policy-making, appropriate strategies, guidelines to further develop, and implications for countries in similar circumstances and characteristics.

Cambodia is located in South-East Asia, which populations about 16.01 million peoples in 2017 and one of the fastest developing countries in Asia with an average GDP growth rate of around 7\% over the past decade. Agriculture played a significant role in national economic development that was sharing about $26.7 \%$ of its GDP and agriculture still employed 42\% of the Kingdom's total workforce in 2017 (EuroCham Cambodia, 2018). Paddy was the most important among food crops for the people in Cambodia (Kea et al., 2017). In 2017, it shared around $6.4 \%$ to GDP or $26.7 \%$ to the agriculture sector which was equivalent to $44.5 \%$ to crops sub-sector (ASPIRE, 2019). The paddy production was increased significantly during the last decade and the production capacity increased more than double from 2003 to 2017. The data revealed that paddy product in 2017 increase to 10.5 million tons in 2017 compared to only 4.7 million tons in 2003 (ASPIRE, 2019). The paddy product in the wet and dry season was 8.04 and 2.46 million tons respectively, these statistics indicated Cambodia's paddy product surplus for exportation reached 5.56 or 3.56 million tons of milled rice product in 2017 (Ministry of Agriculture Forestry and Fisheries [MAFF], 2018). In addition, the paddy's cultivated areas in wet season increased to 2.74 million hectares in 2018 (or 3.4\% increased) up from 2.65 million hectares in 2017 and dry season remained at 0.59 million hectares, likely reflecting challenges in the expanding irrigation system for paddy production, but the paddy product yields of the wet and dry season well increased by $1.7 \%$ and $1.0 \%$ respectively in 2018 (World Bank, 2019). Moreover, figure 1 illustrated that the total paddy product ongoing well increased in three previous years. From this proves, we might assume that paddy product in Cambodia has had high potential and appropriate for the study sample area relevant to the marketing channel.

The objective in this study was to determinant the factors influence marketing channel choices of paddy smallholder farmers in the wet and dry season to be able to reveal out their need to increase productions and investments. Moreover, it also formulates policies to enhance smallholder farmers such as increasing revenue, poverty alleviation, food security, and sustainable development. 


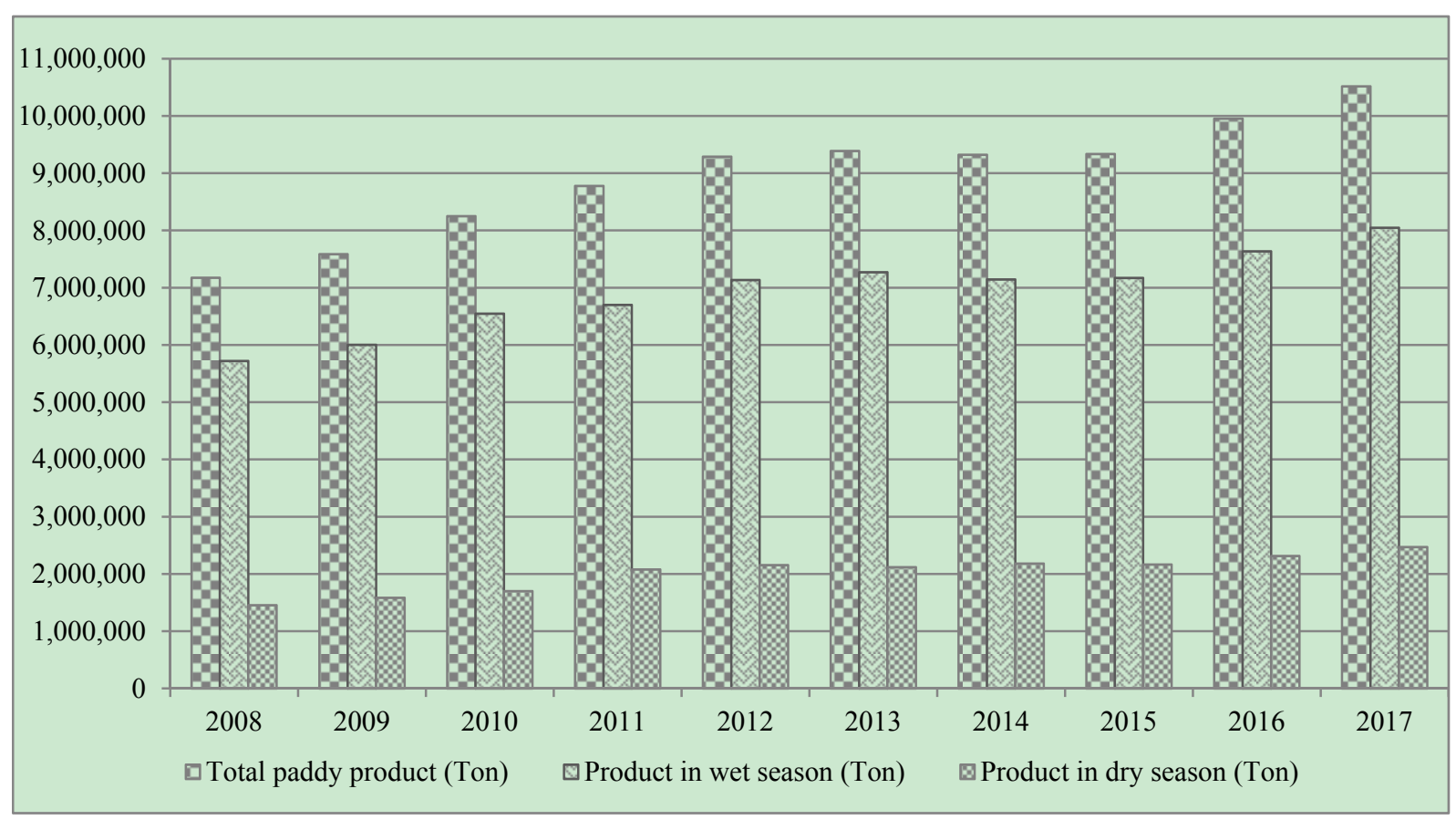

Figure 1. Paddy products in Cambodia

Source: MAFF, 2018

\section{Methodology}

Prey Veng province was distributed 12 districts and 1 town (Prey Veng), 116 communes, and 1139 villages. The populations were $1,057,428$ peoples, the land areas were $4,883 \mathrm{~km}^{2}$ and density per kilometer square were 217 peoples in 2019 (Ministry of Planning, 2019). Geographically, it's located in the southeast of Cambodia, bordering Svay Rieng to the east, Kampong Cham and Tboung Khmum the north, Kandal to the west, and Vietnam to the south with the total borderline of $62.17 \mathrm{~km}$, the annual temperature minimum and maximum is $23.7^{\circ} \mathrm{C}$ and $32.9^{\circ} \mathrm{C}$ respectively (Average: $28.36^{\circ} \mathrm{C}$ ), the average annual rainfall is $1,350 \mathrm{~mm}$ (Council for the Development of Cambodia, 2014). It was also a potential province for crop productions such as yellow maize, sweet potato, mung bean, peanut, sesame, sugar cane, vegetable, and particular paddy production (MAFF, 2018). The total paddy harvested areas and products were 375,321 ha and 1,343,094 tons respectively in 2018. In total, the paddy harvested areas and products were 272,606 ha and 845,099 tons respectively in the wet season, whereas 102,715 ha and 497,995 tons respectively in the dry season (MAFF, 2018). 


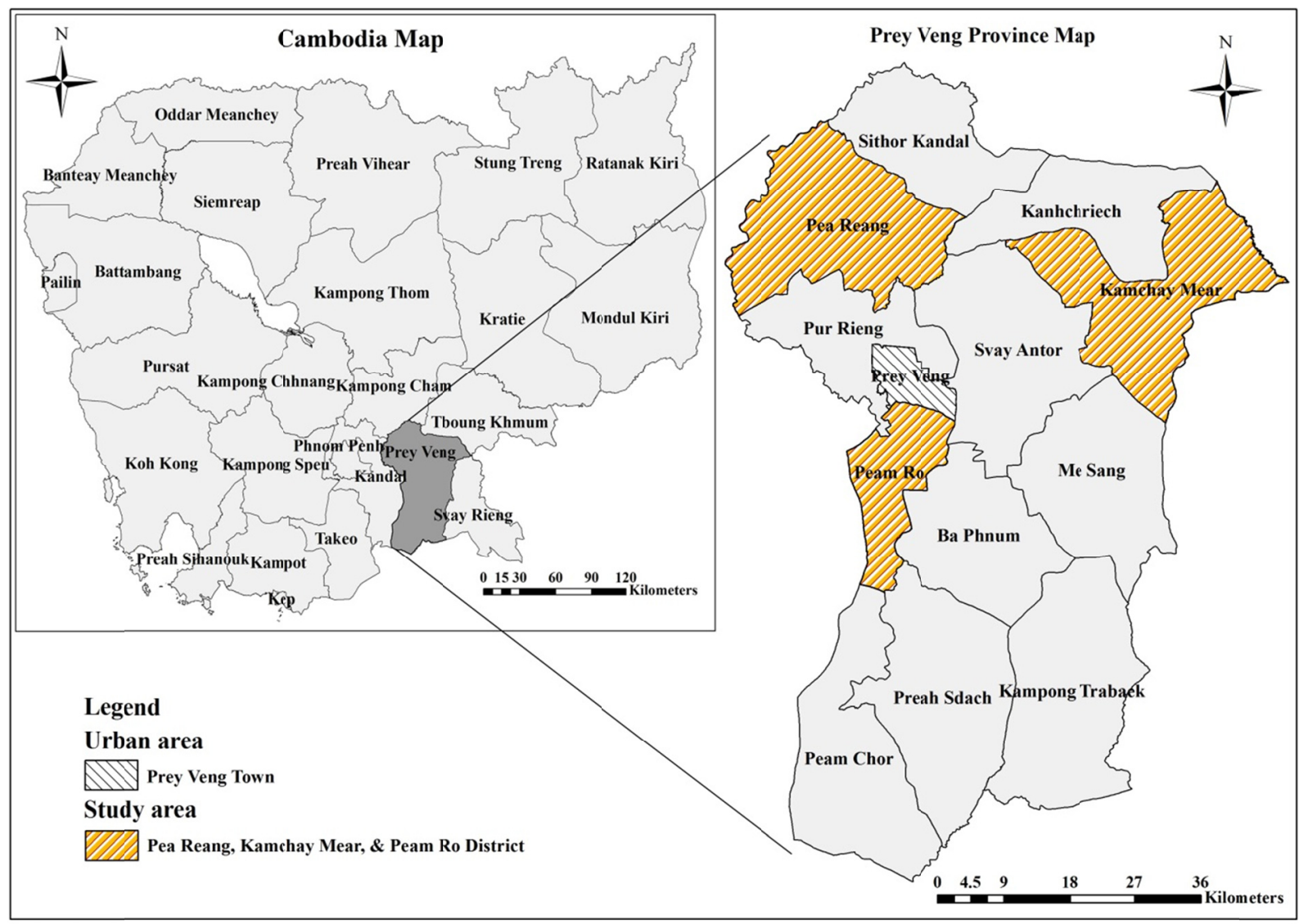

Figure 2. The study area (Source: Prepared by the author using ArcGIS)

The primary data were collected through direct observation to smallholder farmers and 5 various actors with structured and semi-structured interviews by using surveys. The structured interviews, accurate clear questionnaires were designed for smallholder farmers cultivated in the wet and dry season. In the case of semi-structured interviews, in-depth interviews through group discussions with each household farmer were gathered to obtain information related to dependent and independent variables. Dependent variables information related to the marketing channels were selected by smallholder farmers such as collectors, traders, and millers. Independent variables information included socio-economic of the households, institutional, and marketing. Whereas, the 5 various actors were obtained information related to demographic characteristics and marketing. These surveys were conducted in three districts (Pea Reang, Kamchay Mear, and Peam Ro) of Prey Veng province of Cambodia by selecting with technique sampling randomly from January to March 2019. In total, 216 smallholder farmers, 12 collectors, 12 traders, 12 millers, 6 wholesalers, and 6 retailers were interviewed. The Multinomial Logit model was used to estimate by using Stata analysis.

\subsection{Conceptual Framework}

The conceptual framework revealed the interrelationships of the key variables relevant to the study (Figure 3). The socio-economic factors had household information factors such as age, education, experience, household member, household's product quantity, and farming land. The institutional factors had distance from home to the extension office, access to marketing price information, and road quality from farm to the main road. Whereas, marketing factors had distance from farm to the main market, product price, and type of seed. All these factors would be able to influence the decision of smallholder farmers to choose their marketing channels. Therefore, the results would reveal out positive and negative signs related to the marketing channels that might formulate the appropriate policies for development. 


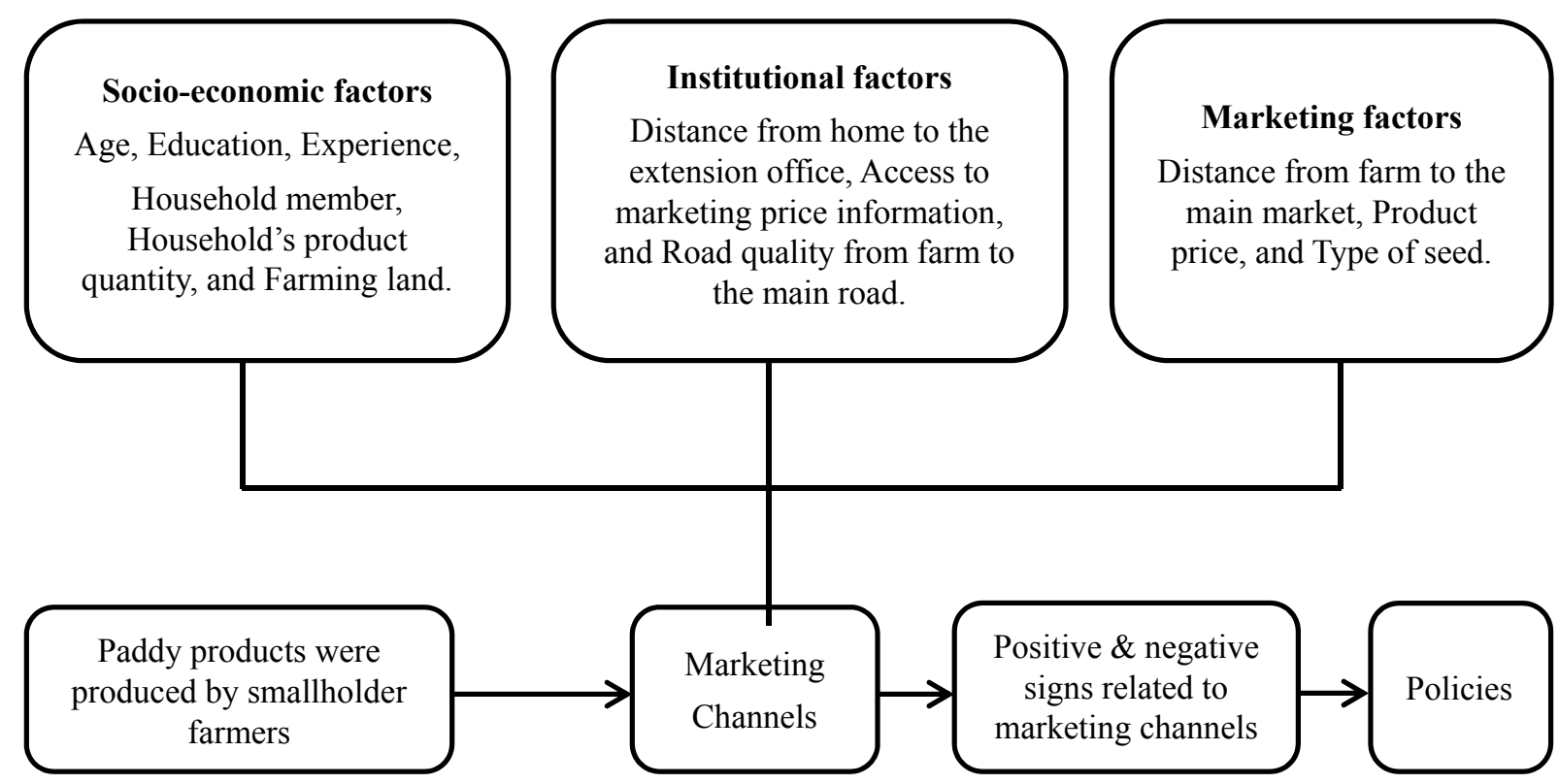

Figure 3. Conceptual framework

\subsection{Econometric Specification}

The marketing channel choices were fundamental and decision for farmers, the conditions had to be considered as a basis for the precise decision. A producer's marketing channel choice was conceptualized by using with Random Utility Model. The model presumed that decide to join in a marketing channel was depending on the maximization of an underlying utility function, and a farmer selected a marketing channel depending on its own expectation utility (McFadden, 1986).

Balsevich et al. (2006) shown that a typical farmer i was presumed to identify N(3) three marketing channel choices, for instance, such as a collector, a trader, or a miller. The utility of the farmers who participated in marketing channel choices $j$ was represented by $U_{i j}$. The benefit marginal cost calculations were expected by farmers depend on the utilities achieved by selling their products to one marketing channel or other. So the utility formula of $\mathrm{U}_{\mathrm{ij}}$ was mentioned as below:

$$
U_{i(j=k)}=\beta_{j=k} X_{i j}+e_{i j} \quad \forall j \in N
$$

Where $U_{\mathrm{ij}}$ : was the utility of each farmer selecting a particular alternative was specified as a linear function of the vector of marketing channel choice specific parameters $\beta_{\mathrm{j}}$ and the attributes of that alternative $X_{\mathrm{ij}}$ and a stochastic error component $\mathrm{e}_{\mathrm{ij}}$.

We could not observe directly the utilities, but a choice was chosen by a farmer shown which one offered the larger utility (Greene, 2003). The probability of selecting an alternative was equal to the probability that the utility of that particular alternative was larger than or equal to the utilities of all other alternatives in the choice set. A farmer opted a marketing channel $\mathrm{j}=\mathrm{k}$ if

$$
U_{i(j=k)}>U_{i(j \neq k)} \quad \forall k \neq j
$$

Where $U_{i j}$ : was a random utility related to marketing channel choice $\mathrm{j}=\mathrm{k} ; \beta_{\mathrm{j}=\mathrm{k}} \mathrm{X}_{\mathrm{ij}}$ : was an index function showing the producer's average utility related to this alternative; and $\mathrm{e}_{\mathrm{ij}}$ : was a random error specific to the utility preference of a producer.

\subsection{Multinomial Logit (MNL) Model of Marketing Channel Choices}

The MNL model was carried out to evaluate factors that affect their marketing channel choices. The model was comprehensively used in the study relate to multiple choices that set in the dependent variables (Gujarati \& Porter, 2009). According to Greene (2003) revealed that if a probability that the $i^{\text {th }}$ farmer selected the $j^{\text {th }}$ of 3 choices was $\mathrm{P}_{\mathrm{ij}}$, the probability that a farmer selected alternative $\mathrm{j}$ could be described by the MNL model as 
below:

$$
P_{i j}=\frac{\exp \left(\beta_{j} x_{i}\right)}{1+\sum_{j=1}^{3} \exp \left(\beta_{j} x_{i}\right)} \quad \text { For } j=1,2,3
$$

Where $\mathrm{x}_{\mathrm{i}}$ : was a vector of all the independent variables that effected to marketing channel choice of the $\mathrm{i}^{\text {th }}$ farmer; and $\beta_{\mathrm{j}}$ : was a vector of regression parameter approximations related to alternative $\mathrm{j}$. So, marketing channel choice $\mathrm{j}=1$ meaning a farmer selected a category $1 ; j=2$ meaning a farmer selected a category 2 ; and $\mathrm{j}=3$ meaning a farmer selected a category 3 .

The coefficient of independent variables in the omitted or a reference category was determined to zero for creating a conditional probability of marketing channel choice was category 3 (Carter-Hill et al., 2008). Setting $\beta_{3}=0$ therefore, the probabilities of the $i^{\text {th }}$ farmers had two other categories were $j=1$ and $j=2$. So we estimated as below:

$$
P_{i}\left(j=m \mid x_{i}\right)=\frac{\exp \left(\beta_{j} x_{i}\right)}{1+\sum_{j=1}^{2} \exp \left(\beta_{j} x_{i}\right)} \quad \text { For } 0<m<3
$$

The estimating coefficients were measured in the MNL model for identifies positive and negative signs related to marketing channels. A positive sign implied relationship with a farmer increased likelihood of selecting its a marketing channel but decreased a reference category. Whereas, a negative sign implied relationship with a farmer decreased likelihood of selecting its a marketing channel but increased a reference category. In addition, a marginal effect of probability in each independent variable was explored the price volume that impacted the marketing channel. Therefore, a marginal effect formula was mentioned as below:

$$
\frac{\partial P_{j}}{\partial X_{i}}=P_{j}\left[\beta_{j}-\sum_{j=0}^{3} P_{j} \beta_{j}\right]=P_{j}\left[\beta_{j}-\bar{\beta}\right]
$$

Where $P_{j}$ : was the probability that a farmer selecting a market it was a marketing channel choice $\mathrm{j}$; and $\beta_{\mathrm{j}}$ : was a vector of regression parameter estimates related to alternative $\mathrm{j}$ (Greene, 2003).

\subsection{Dependent Variables}

The dependent variables denote three marketing channel choices that smallholder farmers in the study sample area sold their products to three different channels such as (1) collectors, (2) traders, and (3) millers. The estimation of the MNL model predicted the relative probability that smallholder farmers selected one among three categories depending on the independent variables. The channel of "Millers" was set as a reference category in both seasons.

\subsection{Independent Variables}

All independent variables were designated depend on the theory fundamental of market participation behavior model premised on utility maximization. The basic assumption of the model was a farmer who decides to maximize utility as a seller was a function of exogenous variables. All these variables captured public-private goods and services which included household social economics, demographic characteristics, road quality, extension services, marketing information, commodities price, etc., that might influence output. In this study was used 12 independent variables such as household head's age (AGE), household head's educations (EDU), farming experience (EXP), household member (HHM), distance from home to the extension office (DEO), distance from farm to the main market (DFM), access to marketing price information (AMP), road quality from farm to the main road (RQR), household's product quantity (HPQ), product price (PP), farming land (FL), and type of seed (TS). So, an empirical MNL model for the factors influencing marketing channel choices by paddy smallholder farmers was mentioned as below:

$$
\begin{gathered}
P_{i j}=\ln \left(\frac{P_{j}}{P_{1}}\right)=\beta_{0}+\beta_{1} A G E+\beta_{2} E D U+\beta_{3} E X P+\beta_{4} H H M+\beta_{5} D E O+\beta_{6} D F M+ \\
\beta_{7} A M P+\beta_{8} R Q R+\beta_{9} H P Q+\beta_{10} P P+\beta_{11} F L+\beta_{12} T S
\end{gathered}
$$

Where $\beta_{0} \ldots \beta_{12}$ : The MNL coefficients were estimated; $P_{\mathrm{ij}}$ : was the probability of marketing channel choices $\mathrm{j}$ being selected by each smallholder farmer i; and

$$
\begin{aligned}
& j=1 \text { for sale to a collector } \\
& j=2 \text { for sale to a trader }
\end{aligned}
$$


$\mathrm{j}=3$ for sale to a miller.

\subsubsection{Description of Independent Variables}

Household head's age (AGE): Older farmers were more likely to choose closer markets for selling their products (Amaya \& Alwang, 2011). Age was able to have a positive relationship with the decision to sell via the informal market (Shiimi et al., 2012). Moreover, older farmers had long-term communication with rural buyers, and young farmers were willing to risk selling to market in the urban areas (Arinloye et al., 2014). Smallholder farmers were able to lose interest in long-distance markets because they might require more time and money as their age increased. So, the expectation of AGE increased the likelihood of smallholder farmers selling to collectors in both seasons.

Household head's education (EDU): education reduced costs and time to process information and activity on that information (Bywaters \& Mlodkowsk, 2012). Mutura et al. (2015) revealed that on the high education of small-scale dairy farmers in Kenya were mostly selling through cooperatives rather than middlemen, due to they understood and accessed to market information. The formal education level was used as the way of farmers' ability to gain access synthesis and carried out to integrated information from different sources effectively (Strauss et al., 1991). Farmer \& Betz (2016) found that well education of West Virginian farmers was more likely to sell to directly consumers, which implied that farmers who higher educations had abilities to find the information and took risks in direct marketing channels. The education was able to reveal the role of human capital helped to alleviate operating costs. So, EDU level was expected to have positive sign relationship of smallholder farmers sold to millers in wet and traders in the dry season.

Table 1. Description of dependent and independent variables and expected sign

\begin{tabular}{|c|c|c|c|c|c|c|}
\hline \multicolumn{7}{|c|}{ Dependent variables } \\
\hline Variable & Description & \multicolumn{5}{|c|}{ Measurement } \\
\hline The & \multirow{3}{*}{ Sale to collectors, traders, and millers. } & \multicolumn{5}{|c|}{$1=$ Sale to a collector } \\
\hline marketing & & \multirow{2}{*}{\multicolumn{5}{|c|}{$\begin{array}{l}2=\text { Sale to a trader } \\
3=\text { Sale to a miller. }\end{array}$}} \\
\hline channels & & & & & & \\
\hline \multicolumn{7}{|c|}{ Independent variables } \\
\hline \multirow{3}{*}{ Variable } & \multirow{3}{*}{ Description } & \multirow{3}{*}{ Measurement } & \multicolumn{4}{|c|}{ Expected sign } \\
\hline & & & \multicolumn{2}{|c|}{ Wet season } & \multicolumn{2}{|c|}{ Dry season } \\
\hline & & & Coll. & Tra. & Coll. & Tra. \\
\hline AGE & Household head's age & Year & + & + & + & - \\
\hline EDU & Household head's education & Year & - & - & - & + \\
\hline EXP & Farming experience & Year & - & - & - & + \\
\hline HHM & Household member & Person & + & + & + & - \\
\hline DEO & $\begin{array}{c}\text { Distance from home to the extension } \\
\text { office }\end{array}$ & Kilometer & + & + & + & - \\
\hline DFM & Distance from farm to the main market & Kilometer & + & + & + & - \\
\hline AMP & Access to marketing price information & $1=$ Yes, $0=$ No & - & - & - & + \\
\hline RQR & $\begin{array}{l}\text { Road quality from farm to the main } \\
\text { road }\end{array}$ & $\begin{array}{c}1=\text { Very poor, } 2=\text { Poor, } \\
3=\text { Average, } 4=\text { Good, } \\
5=\text { Very good }\end{array}$ & - & - & - & + \\
\hline HPQ & Household's product quantity & Ton & + & + & + & - \\
\hline PP & Product price & $\mathrm{Riel} / \mathrm{Kg}$ & - & - & - & + \\
\hline FL & Farming land & Hectare & - & - & - & + \\
\hline $\mathrm{TS}$ & Type of seed & $\begin{array}{c}1=\text { Early rice } \\
2=\text { Medium rice, } \\
3=\text { Late rice }\end{array}$ & - & - & - & - \\
\hline
\end{tabular}

Farming experience (EXP): the experience was able also to reflect the ability to bargain for choosing a better market for the benefit of the seller (Renos et al., 2003). Adanacioglu (2017) mentioned in the research of cherry farming in the Kemalpasa District of Izmir of Turkey were farmers who had higher than 20 years' experience tended to select direct marketing channels. A farmer who had more experiences of farming might increase 
capacity and be able to have good relationships with end-users. So, EXP of the household head was expected the positive sign relationship to increase the likelihood of smallholder farmers choosing millers in wet and traders in the dry season was the direct marketing channels.

Household member (HHM): the family size factor related to labor availability (Higuchi et al., 2012; Abebe et al., 2016) and it had product surplus for selling in the market (Girma \& Abebaw, 2012). According to Monson et al. (2008) found that statistically significant negative related to large families tended to sell less of their products to direct marketing channels. The large family size was able to help to produce more products but might lack storage capacity and transportation so that it might influence the decision of smallholder farmers to choose closer markets. The HHM of variable was expected to increase the likelihood of using the indirect marketing channels in both seasons.

Distance from home to the extension office (DEO): was set from a farmer's location to an extension office that locates in his/her district and it was measured in kilometer. Smallholder farmers located near the extension office might easily access new technologies such as high yield seed, rice farming modern, and other new farming practices, that might urge them to produce high quality and quantity for enhancement of their livelihood. According to Waqar et al. (2018) revealed that negatively significant distance from farm to the extension office. Therefore, DEO of the variable was expected to decrease the likelihood of using direct marketing channels in the wet and dry season.

Distance from farm to the main market (DFM): was set from a farming location to the main market which he/she used to sell in a district, or urban, or elsewhere market and it was measured in kilometer. The price addition to production cost through long-distance to the main market made farmers were less likely to join in the market due to the high shipping charges of transportation (Omamo, 1998). The longer distances affected the transportation cost increased (Maina et al., 2015). According to Tsourgiannis et al. (2008) found that the long way from market influence farmers sold tendencies to the monopolistic local marketing channels. It might be construed as specific additional costs for transportation to the market and influencing decreased likelihood to direct marketing channels. So, DFM of the variable was expected the positive sign relationship of smallholder farmers used indirect marketing channels in both seasons.

Access to marketing price information (AMP): smallholder farmers that used the marketing price information might be important due to it enabled them to make more appropriate decisions of selling their products in the market. All farmers that had insufficient market information were more likely to sell their paddy products at the farm gate and less likely to sell to the direct marketing channels (Soe et al., 2015). Mmbando et al. (2016) revealed that smallholder farmers who used marketing price information had significant positive related to increase the probability that maize producers sold to the direct marketing channels. The AMP of the variable was set as a dummy variable and it was expected to increase the likelihood of smallholder farmers chose the direct marketing channels in both seasons.

Road quality from farm to the main road (RQR): it was expected a positive influence on market participation depends on the road quality access to the main markets (Jari \& Fraser, 2009). Farmers near the main road had better access to market information and transportation (Getahun et al., 2017). The operating costs might increase due to bad road conditions, so smallholder farmers who face the low-quality road surface might sell their product to collectors. The RQR was ranged from 1 to 5 (1=very poor, 2=poor, $3=$ average, $4=$ good, and $5=$ very good). The variable of RQR was expected to increased the probability of smallholder farmers sold to millers in wet and traders in the dry season.

Household's product quantity (HPQ): the total paddy product of a household was measured in tons. According to Jari (2009) shown the evidence that households had semi-commercial farming would produce for their consumption and sold to the market of product surplus. Kyaw et al. (2018) found that the total products of rice had significantly positively and influence the proportion of rice sales in the market. Farmers who had large productions increased the ratio sold in the market and were more likely to sell to wholesalers (Abebe et al., 2016). In another hand, a large volume of products might help smallholder farmers earn more profits, but it might also be a consequence of shipping to the market. Resulting, smallholder farmers might choose the markets near their homes and reduced their profits. Therefore, the variable of HPQ was expected to increase the likelihood of selecting the indirect marketing channels in both seasons.

Product price (PP): price was very important to promote and incentives for smallholder farmers might choose appropriate marketing channels. According to Azam et al. (2012) because of price increased hopefully it boosted farmers to produce a large volume of yield that increased market participation and more acceptance benefit from market choices. Gelaw et al. (2016) determined that the main significant factors to selecting traders by coffee 
farmers in Ethiopia were the price due to they got a high price on the channel. Therefore, PP of the variable was expected to decrease the likelihood to collectors and traders in wet but increased likelihood to traders in the dry season.

Farming land (FL): smallholder farmers who had large farming land might increase the likelihood had multi agriculture such as paddy productions, other crops, or livestock productions. This variable might have a positive sign related to marketing channels due to a farmer was able to have many relationships with markets and multi choices. It was determined with the land that active in agriculture, for instance, a farmer might cultivate in wet more than the dry season. Therefore, a farmer's FL might have a different size between both seasons. Abebe et al (2016) farming size were identified as a factor that shows the volume of production and quantity sold in the market. De Bruyn et al. (2001) shown that an increase in farming size pushed to an increase in the ratio of crop production that was available for markets and higher willingness to sell. So, FL of the variable was expected to increase the likelihood of smallholder farmers sold to millers in wet and traders in the dry season.

Type of seed (TS): in the annual report for agriculture forestry and fisheries 2017-2018 and direction 2018-2019 was published by Cambodia's Ministry of Agriculture, Forestry and Fisheries, there were 5 types of rice seeds such as early, medium (middle), late, upland, and floating rice in Cambodia (MAFF, 2018). But in the study sample area had only 3 rice seeds such as early, medium, and late rice. The values for TS was ranged from 1 to 3 ( $1=$ early rice, $2=$ medium rice, $3=$ late rice). The type of seed might influence a farmer's marketing channel because a buyer might provide a different price to different seed. Therefore, TS of the variable was expected to increase the likelihood of millers in both seasons.

\section{Results and Discussion}

\subsection{Descriptive Statistics of Variables}

\subsubsection{Marketing Channel Description}

\section{- Type of seed statistics}

In the study sample area, rice seeds were known type and recalled name by farmers such as early rice had IR504, IR(OM), IR66, and IR; medium rice had Neang Khun, Phka Khnhey, Tro Nung, IR dom nerb, and Kro Saing Teab; and late rice had Jasmine, Mom Meang, Somaly, Phka Rumduol, and so forth.

Table 2. Descriptive statistics type of seed

\begin{tabular}{ccccc}
\hline \multirow{2}{*}{ Type of seed } & \multicolumn{2}{c}{ Wet season } & \multicolumn{2}{c}{ Dry season } \\
\cline { 2 - 5 } & Percent (\%) & Sample & Percent (\%) & Sample \\
\hline Early rice & 28.24 & 61 & 80.09 & 173 \\
Medium rice & 50.46 & 109 & 12.50 & 27 \\
Late rice & 21.30 & 46 & 7.41 & 16 \\
Total & 100 & 216 & 100 & 216 \\
\hline
\end{tabular}

The early rice in the wet and dry season was $28.24 \%$ and $80.09 \%$ respectively, medium rice in the wet and dry season was $50.46 \%$ and $12.50 \%$ respectively, and late rice in the wet and dry season was $21.30 \%$ and $7.41 \%$ respectively. In the wet season, smallholder farmers mostly cultivated medium and early rice (medium $>$ early $>$ late rice) due to the extent of irrigation systems might be large, but the late rice cultivation was smaller than other because it might be spent time, high production costs, and high threatens. Whereas in the dry season, due to the water supply might be insufficient so that it urged they cultivate mostly early and medium rice (early $>$ medium $>$ late rice).

- Marketing channels in the study sample area

Collectors at the farm gate (Collectors): were the small-medium size of paddy buyers or brokers who bought paddy products from producers such as early, medium, and late rice. They were generally near the farm gate and usually sold mostly early rice to traders, and medium and late rice to millers (Table 3).

Traders near the main market (Traders): were the paddy buyers who mostly near the main market and bought paddy products from producers, collectors, and millers. They sold medium and late rice mostly to millers and exported early rice (Table 3). Moreover, smallholder farmers produced mostly early rice about $80.09 \%$ in the dry season (Table 2). From this evidences, we might assume that traders were direct marketing channels in the dry season. 
Millers near village/town (Millers): were the paddy buyers who bought paddy products from producers, collectors, and traders. They sold mostly early rice to traders and generated paddy products of medium and late rice to milled rice products (Table 3). Moreover, smallholder farmers produced medium and late rice about $71.76 \%$ in the wet season (Table 2). From this evidences, we might assume that millers were direct marketing channels in the wet season. The millers sold their milled rice products to wholesalers, retailers, consumers, and exportation.

Table 3. Various actors marketing channel statistics

\begin{tabular}{cccccc}
\hline \multirow{2}{*}{ Various actor } & Season & Market & \multicolumn{3}{c}{ Type of seed } \\
\cline { 3 - 5 } Collectors & Wet & To traders & Early rice (\%) & Medium rice (\%) & Late rice (\%) \\
\hline \multirow{2}{*}{ (12 Samples) } & & To millers & 25 & 8.33 & 0 \\
& \multirow{2}{*}{ Dry } & To traders & 91.67 & 91.67 & 100 \\
& & To millers & 8.33 & 63.33 & 16.67 \\
Traders & \multirow{2}{*}{ Wet } & To millers & 0 & 83.33 & 83.33 \\
$(12$ Samples) & \multirow{2}{*}{ Dry } & Exportation & 100 & 16.67 & 100 \\
& & To millers & 0 & 75 & 0 \\
& \multirow{2}{*}{ Wet } & Exportation & 100 & 25 & 100 \\
$(12$ Samples) & \multirow{2}{*}{ Dry } & To traders & 83.33 & 0 & 0 \\
& & Generated to milled rice & 16.67 & 100 & 100 \\
\hline & & To traders & 100 & 0 & 0 \\
\hline
\end{tabular}

\section{Marketing channels in the wet season}

Channel 1: Producers $\rightarrow$ collectors $\rightarrow$ traders $\rightarrow$ millers $\rightarrow$ wholesalers $\rightarrow$ retailers $\rightarrow$ consumers.

Channel 2: Producers $\rightarrow$ traders $\rightarrow$ millers $\rightarrow$ wholesalers $\rightarrow$ retailers $\rightarrow$ consumers.

Channel 3: Producers $\rightarrow$ millers $\rightarrow$ wholesalers $\rightarrow$ retailers $\rightarrow$ consumers.

\section{Marketing channels in the dry season}

Channel 1: Producers $\rightarrow$ collectors $\rightarrow$ millers $\rightarrow$ traders $\rightarrow$ foreign markets (Vietnam/Thailand).

Channel 2: Producers $\rightarrow$ traders $\rightarrow$ foreign markets (Vietnam/Thailand).

Channel 3: Producers $\rightarrow$ millers $\rightarrow$ traders $\rightarrow$ foreign markets (Vietnam/Thailand).

The marketing channels of study sample area (Figure 4) were designed detail including both seasons with two sections such as paddy flow and milled rice flow. 


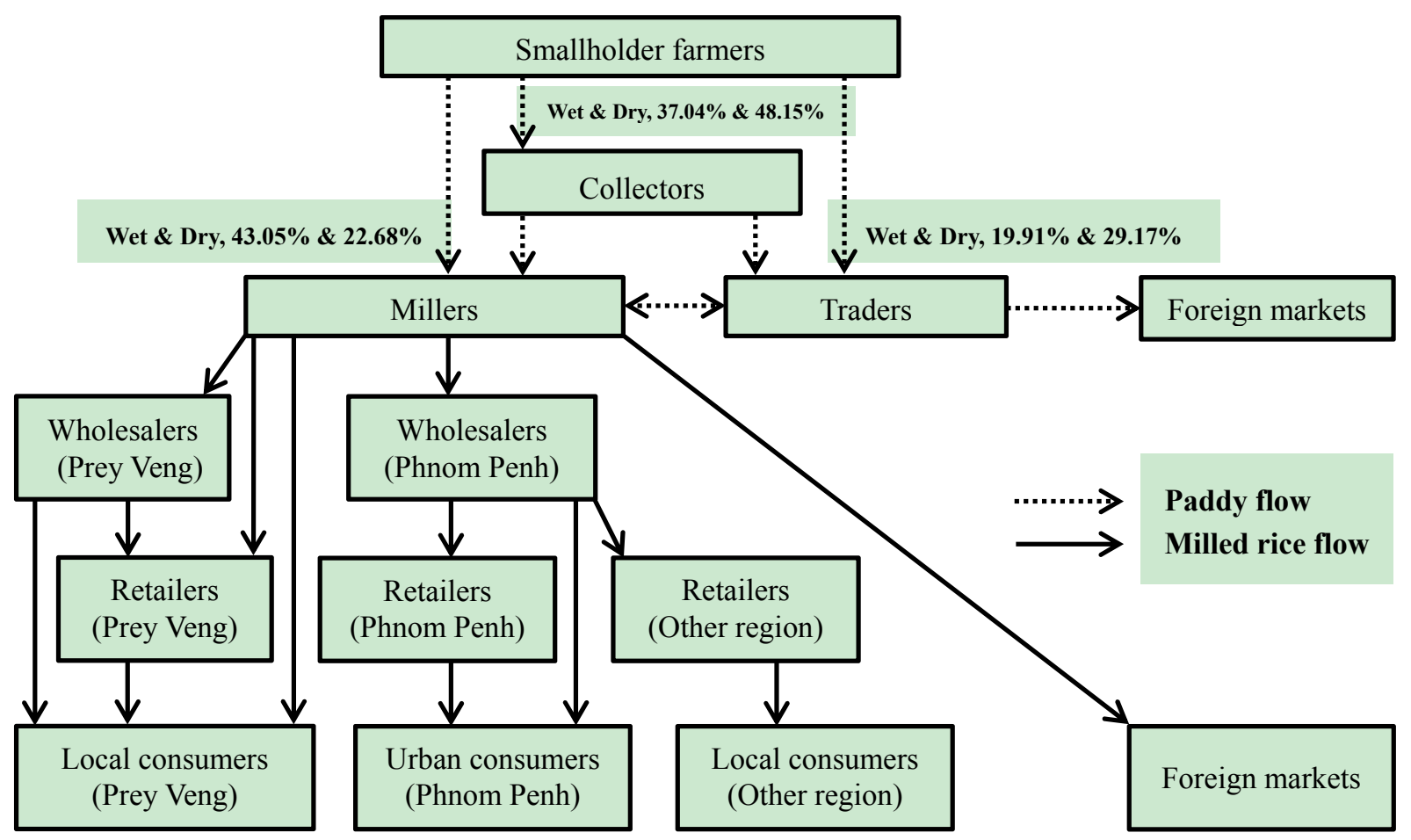

Figure 4. Marketing channels of the study sample area

\subsubsection{Dependent Variables Statistics}

About $37.04 \%$ and $48.15 \%$ respectively of smallholder farmers sold their paddy products in the wet and dry season to collectors. They sold the paddy products to traders in the wet and dry season were about $19.91 \%$ and $29.17 \%$ respectively. Whereas about $43.05 \%$ and $22.68 \%$ respectively of them sold the paddy products to millers in the wet and dry season.

Table 4. Smallholder farmers participated in the marketing channels

\begin{tabular}{ccccc}
\hline \multirow{2}{*}{ Marketing channels } & \multicolumn{2}{c}{ Wet season } & \multicolumn{2}{c}{ Dry season } \\
\cline { 2 - 5 } & Percent (\%) & Sample & Percent (\%) & Sample \\
\hline Collectors & 37.04 & 80 & 48.15 & 104 \\
Traders & 19.91 & 43 & 29.17 & 63 \\
Millers & 43.05 & 93 & 22.68 & 49 \\
Total & 100 & 216 & 100 & 216 \\
\hline
\end{tabular}

\subsubsection{Independent Variables Statistics}

As mentioned earlier, an MNL model was used to identify factors influencing marketing channels with the description of independent variables that were given 12 variables. In table 5 and 6 were revealed the statistics of independent variables in the wet and dry season which separated two parts. 
Table 5. Description statistics of independent variables were used in the model of the wet season

\begin{tabular}{|c|c|c|c|c|c|c|c|c|c|c|}
\hline \multirow{2}{*}{ Variable } & \multicolumn{2}{|c|}{$\begin{array}{c}\text { Collectors } \\
(\mathrm{N}=\mathbf{8 0})\end{array}$} & \multicolumn{2}{|c|}{$\begin{array}{l}\text { Traders } \\
(\mathrm{N}=43)\end{array}$} & \multicolumn{2}{|c|}{$\begin{array}{l}\text { Millers } \\
(\mathrm{N}=93)\end{array}$} & \multicolumn{4}{|c|}{$\begin{array}{c}\text { Total } \\
(\mathrm{N}=\mathbf{2 1 6})\end{array}$} \\
\hline & Mean & Std. De. & Mean & Std. De. & Mean & Std. De. & Mean & Std. De. & Min & Max \\
\hline AGE & 43.63 & 8.40 & 47.26 & 11.53 & 39.65 & 8.34 & 42.63 & 9.50 & 23 & 66 \\
\hline EDU & 7.43 & 3.23 & 9.67 & 3.42 & 8.90 & 3.06 & 8.51 & 3.30 & 0 & 16 \\
\hline EXP & 17.05 & 8.75 & 15.14 & 9.69 & 15.41 & 7.33 & 15.96 & 8.38 & 1 & 38 \\
\hline HНM & 6.24 & 1.26 & 7.09 & 2.14 & 6.45 & 1.47 & 6.50 & 1.58 & 3 & 11 \\
\hline DEO & 16.69 & 4.86 & 14.44 & 7.45 & 14.05 & 4.99 & 15.11 & 5.62 & 2 & 23 \\
\hline DFM & 24.09 & 8.52 & 15.22 & 10.64 & 17.02 & 9.81 & 19.28 & 10.20 & 3 & 35 \\
\hline AMP & 0.20 & 0.40 & 0.21 & 0.41 & 0.45 & 0.50 & 0.31 & 0.46 & 0 & 1 \\
\hline RQR & 1.75 & 0.88 & 2.56 & 0.88 & 3.14 & 0.73 & 2.51 & 1.03 & 1 & 5 \\
\hline HPQ & 9.61 & 6.76 & 13.14 & 7.02 & 11.55 & 9.05 & 11.15 & 7.95 & 1.05 & 54 \\
\hline PP & 763.50 & 98.15 & 823.95 & 152.55 & 969.78 & 188.35 & 864.35 & 179.40 & 680 & 1200 \\
\hline FL & 2.80 & 1.99 & 3.81 & 1.93 & 3.92 & 2.45 & 3.48 & 2.24 & 0.5 & 14.8 \\
\hline TS & 1.65 & 0.62 & 2.02 & 0.77 & 2.13 & 0.66 & 1.93 & 0.70 & 1 & 3 \\
\hline
\end{tabular}

Note. $1 \$=4000$ Riel

Part 1: six independent variables' statistics values were the same between wet and dry season such as the total average of household head's age (AGE) was 42.63 years, household head's education (EDU) was 8.51 years, farming experience (EXP) was 15.96 years, household member (HHM) was 6.5 persons, distance from home to the extension office (DEO) was 15.11 kilometers, and distance from farm to the main market (DFM) was 19.28 kilometers (Table 5).

Table 6. Description statistics of independent variables were used in the model of the dry season

\begin{tabular}{|c|c|c|c|c|c|c|c|c|c|c|}
\hline \multirow[t]{2}{*}{ Variable } & \multicolumn{2}{|c|}{$\begin{array}{c}\text { Collectors } \\
(\mathrm{N}=104)\end{array}$} & \multicolumn{2}{|c|}{$\begin{array}{c}\text { Traders } \\
(\mathbf{N}=63)\end{array}$} & \multicolumn{2}{|c|}{$\begin{array}{l}\text { Millers } \\
(\mathrm{N}=49)\end{array}$} & \multicolumn{4}{|c|}{$\begin{array}{c}\text { Total } \\
(\mathrm{N}=216)\end{array}$} \\
\hline & Mean & Std. De. & Mean & Std. De. & Mean & Std. De. & Mean & Std. De. & Min & Max \\
\hline AGE & 43.07 & 8.14 & 41.89 & 12.34 & 42.67 & 7.99 & 42.63 & 9.50 & 23 & 66 \\
\hline EDU & 7.31 & 3.05 & 10.56 & 3.00 & 8.43 & 2.94 & 8.51 & 3.30 & 0 & 16 \\
\hline EXP & 17.06 & 8.60 & 13.35 & 7.83 & 17.00 & 7.99 & 15.96 & 8.38 & 1 & 38 \\
\hline HHM & 6.14 & 1.27 & 6.94 & 2.06 & 6.69 & 1.28 & 6.50 & 1.58 & 3 & 11 \\
\hline DEO & 15.14 & 5.16 & 15.32 & 6.47 & 14.76 & 5.50 & 15.11 & 5.62 & 2 & 23 \\
\hline DFM & 23.68 & 7.35 & 10.63 & 9.19 & 21.06 & 9.90 & 19.28 & 10.20 & 3 & 35 \\
\hline AMP & 0.22 & 0.42 & 0.65 & 0.48 & 0.31 & 0.47 & 0.37 & 0.48 & 0 & 1 \\
\hline RQR & 3.35 & 0.64 & 3.98 & 0.77 & 3.57 & 0.79 & 3.58 & 0.76 & 2 & 5 \\
\hline HPQ & 14.69 & 10.65 & 11.33 & 6.67 & 13.24 & 8.50 & 13.38 & 9.24 & 1.33 & 60.41 \\
\hline PP & 714.13 & 28.31 & 770.56 & 106.57 & 726.53 & 43.42 & 733.40 & 68.37 & 660 & 1200 \\
\hline FL & 3.25 & 2.39 & 3.15 & 1.75 & 3.29 & 2.19 & 3.23 & 2.16 & 0.4 & 13.4 \\
\hline TS & 1.16 & 0.46 & 1.27 & 0.68 & 1.51 & 0.65 & 1.27 & 0.59 & 1 & 3 \\
\hline
\end{tabular}

Note. $1 \$=4000$ Riel

Part 2: six independent variables' statistics values were different between wet and dry season such as the total average of access to market information (AMP) in the wet and dry season was 0.31 and 0.37 respectively, road quality from farm to the main road (RQR) in the wet and dry season was 2.51 and 3.58 respectively, household's 
product quantity (HPQ) in the wet and dry season was 11.15 and 13.38 tons respectively, product price (PP) in the wet and dry season was 864.35 and $733.40 \mathrm{riel} / \mathrm{kg}$ respectively, farming land (FL) in the wet and dry season was 3.48 and 3.23 hectares respectively, and type of seed (TS) in the wet and dry season was 1.93 and 1.27 respectively (Table 5 and 6 ).

\subsection{Influencing Factors on Marketing Channel Choice}

\subsubsection{Influencing Factors in the Wet Season}

All the variables were estimated coefficients and marginal effects showed that AGE, EXP, DEO, DFM, RQR, HPQ, PP, FL, and TS influenced to marketing channel choices that were made by smallholder farmers, but had different effects based on the marketing channels in the wet season (Table 7). Household head's age (AGE): had both positives related to marketing channels choice as expected and significant at $5 \%$ and $1 \%$ level respectively of using collectors and traders. It increased the likelihood that a paddy farmer sold to a collector and a trader by the probability was about $0.88 \%$ and $2.60 \%$ respectively relative to a miller for every additional one year. Meaning that, older smallholder farmers were more likely to sell their products through closer markets were the indirect marketing channels. This result was in accordance with Amaya \& Alwang (2011) found that older farmers tend to sell to closer markets.

Farming experience (EXP): had a negative sign as expected and it was significant at $1 \%$ level. It reduced the likelihood that a farmer sold to a trader relative to a miller by marginal effect about $2.08 \%$ if an additional one year. More experiences of smallholder farmers were more likely to select direct marketing channels to increase their profits. This result was in accordance with Adanacioglu (2017) found that farmers who had higher than 20 years' experience tended to select the direct marketing channels.

Distance from home to the extension office (DEO): was a positive sign as expected and significant at $1 \%$ level. It increased the likelihood that a farmer used a collector by marginal effect about $3.10 \%$ if one kilometer additional from the extension office relative to a miller was decreased. This meaning that, smallholder farmers who lived in the remote areas far from the extension office were more likely to sell to closer markets as the indirect marketing channels and reduced their profits. This result was consistent with Waqar et al. (2018) found that negatively significant distance from farm to the extension office.

Distance from farm to the main market (DFM): revealed a positive sign as expected and it was significant at $1 \%$ level. It increased the likelihood that a farmer sold to a collector relative to a miller with a probability of about $1.84 \%$. Smallholder farmers who lived farther away from the main markets were more likely to sell their products to collectors as indirect marketing channels due to they might face high transportation costs, spent times, and lack of own transportation. This result was consistent with Mmbando et al. (2016) found that farmers located in remote areas from markets challenged to high transportation costs and stimulated to choose the brokers at the farm gate more than sold to wholesalers.

Road quality from farm to the main road (RQR): the coefficients were both negatives sign as expected and both statistically significant at $1 \%$ level. Those imply that it decreased the probability that a farmer sold to a collector and a trader by marginal effect about $37.26 \%$ and $2.98 \%$ respectively relative to a miller. This could be explained that, smallholder farmers located in high-quality road infrastructure were less likely to sell their products to indirect and more likely to direct marketing channels. This result was in accordance with Jari \& Fraser (2009) revealed that the availability of high-quality road infrastructure increased the high probability of households sold their products through the direct channel in South Africa. 
Table 7. Factors influenced the marketing channel choices in the wet season

\begin{tabular}{ccccc}
\hline \multirow{2}{*}{ Variable } & \multicolumn{2}{c}{ Collectors vs Millers contrast } & \multicolumn{2}{c}{ Traders vs Millers contrast } \\
\cline { 2 - 5 } & $\begin{array}{c}\text { Estimated } \\
\text { coefficients }\end{array}$ & $\begin{array}{c}\text { Marginal } \\
\text { effects (dy/dx) }\end{array}$ & $\begin{array}{c}\text { Estimated } \\
\text { coefficients }\end{array}$ & $\begin{array}{c}\text { Marginal } \\
\text { effects (dy/dx) }\end{array}$ \\
\hline \multirow{2}{*}{ Constant } & $8.0584^{* * *}$ & - & -2.2336 & - \\
& $(2.8239)$ & 0.0088 & $(2.4242)$ & 0.0260 \\
AGE & $0.1096^{* *}$ & $(0.0075)$ & $(0.044 * 9)$ & $(0.0070)$ \\
& $(0.0472)$ & -0.0286 & 0.0610 & 0.0215 \\
EDU & -0.1252 & $(0.0153)$ & $(0.0824)$ & $(0.0147)$ \\
& $(0.0844)$ & -0.0012 & $-0.1221^{* * *}$ & -0.0208 \\
EXP & -0.0526 & $(0.0081)$ & $(0.0450)$ & $(0.0077)$ \\
& $(0.0501)$ & -0.0393 & 0.1715 & 0.0447 \\
HHM & -0.1389 & $(0.0319)$ & $(0.1424)$ & $(0.0259)$ \\
& $(0.1876)$ & 0.0310 & 0.0137 & -0.0094 \\
DEO & $0.1659^{* * *}$ & $(0.0095)$ & $(0.0431)$ & $(0.0077)$ \\
& $(0.0542)$ & 0.0184 & 0.0123 & -0.0048 \\
DFM & $0.1004^{* * *}$ & $(0.0050)$ & $(0.0260)$ & $(0.0048)$ \\
& $(0.0302)$ & -0.0886 & -0.3277 & -0.0248 \\
AMP & -0.6019 & $(0.1144)$ & $(0.6318)$ & $(0.1154)$ \\
& $(0.7094)$ & -0.3726 & $-0.9823 * * *$ & -0.0298 \\
RQR & $-2.3067^{* * *}$ & $(0.0769)$ & $(0.3532)$ & $(0.0598)$ \\
& $(0.4116)$ & 0.0241 & $0.1831^{* *}$ & 0.0227 \\
HPQ & $0.1945^{*}$ & $(0.0192)$ & $(0.0888)$ & $(0.0166)$ \\
& $(0.1093)$ & -0.0011 & $-0.0043 * *$ & -0.0003 \\
PP & $-0.0074^{* * *}$ & $(0.0004)$ & $(0.0018)$ & $(0.0003)$ \\
& $(0.0022)$ & -0.1283 & $-0.5614 *$ & -0.0491 \\
FL & $-0.8787^{* *}$ & $(0.0668)$ & $(0.3373)$ & $(0.0628)$ \\
& $(0.3873)$ & -0.1933 & 0.3106 & 0.1273 \\
TS & $-0.8858^{* *}$ & $(0.0771)$ & $(0.4069)$ & $(0.0699)$ \\
\hline
\end{tabular}

Note. Reference category: Millers; $* * *, * * \& *$ indicated significant at $1 \%, 5 \%$, and $10 \%$ respectively; in the parentheses were value of SE

Household's product quantity (HPQ): had both positives sign as expected and the statistically significant was at $10 \%$ and 5\% level. Both positives sign implies the likelihood of a farmer sold to a collector and a trader increased by marginal effect about $2.41 \%$ and $2.27 \%$ respectively relative to a miller if an additional one ton. The results showed that smallholder farmers had high products sold to indirect marketing channels increased due to they might challenge with high transportation costs, lack of transportation infrastructures, and storage items.

Product price (PP): had both significant negatives sign as expected with significant were at $1 \%$ and $5 \%$ level. It decreased the likelihood that a farmer sold to a collector and a trader relative to a miller was increased. This could be explained that prices were high in the market urged smallholder farmers to produce large volumes, enhancing marketing participation, and availability of high profitable in direct marketing channels. This result was consistent with Zivenge \& Karavina (2012) shown that a positive sign influencing the relationship between the producer's price and marketing channel choice for communal horticulture farmers in Zimbabwe.

Farming land (FL): had both negatives sign as expected and significant were at $5 \%$ and $10 \%$ level. This showed that, if one hectare increased, the probability that a farmer would sell to a collector and a trader would decrease by marginal effect about $12.83 \%$ and $4.91 \%$ respectively relative to a miller. This meaning that, smallholder farmers who had large of FL chose millers increased for selling their products relative to collectors and traders due to they might have multi farming and more relationship with buyers. So, smallholder farmers with large production had greater willingness to sell to direct marketing channels.

Type of seed (TS): was a negative sign as expected and it was significant at $5 \%$ level. It reduced the likelihood that a farmer sold to a collector relative to a miller by marginal effect about $19.33 \%$. This meaning that, it increased the likelihood to millers because millers tended to buy medium and late rice by generated to milled rice products for local domestic consumption of household food and exportation that might stimulate the price increased rather than early rice tended to sell to traders (Table 3). 


\subsubsection{Influencing Factors in the Dry Season}

Estimated coefficients and marginal effects showed that EDU, HHM, DFM, AMP, RQR, HPQ, PP, FL, and TS all influencing the marketing channel choices were made by smallholder farmers (Table 8), but had different impacts based on the marketing channels in the dry season. Household head's education (EDU): had significant a negative and a positive sign related to the marketing channels as expected with both significant at $10 \%$ level of using collectors and traders. It reduced the probability that a paddy farmer sold to a collector by about $4.82 \%$ for every additional a year relative to a miller. Whereas, the probability of a farmer sold to a trader increased by about $3.21 \%$. Smallholder farmers would be improved by education for appropriate decisions in the marketing channel due to they sold to millers rather than collectors and sold to traders as the direct marketing channels rather than millers. This result was consistent with Mmbando et al. (2016) found that the household head's education increased the likelihood of a maize producer sold to wholesaler nearby town relative to broker.

Household member (HHM): had a negative sign and it was significant at 5\% level. According to Shephard et al. (2011) said that households of large member's sizes had not the ability to produce a marketable surplus due to household's consumption needs and Kyaw et al. (2018) large families of the rural areas had less agricultural products for sale in the market. These meanings and our expectation were opposite with results, the probability that a farmer sold to a collector decreased by marginal effect about $7.73 \%$ if added one member relative to a miller was increased. Whereas, traders not significant but the coefficient positive sign that might relate to increasing the likelihood. This could be explained that the large member's size was very important to enhance smallholder farmers sold their products to direct marketing channel due to large members were high labor that might urge high productivity and more relationships with buyers.

Table 8. Factors influenced the marketing channel choices in the dry season

\begin{tabular}{|c|c|c|c|c|}
\hline \multirow[b]{2}{*}{ Variable } & \multicolumn{2}{|c|}{ Collectors vs Millers contrast } & \multicolumn{2}{|c|}{ Traders vs Millers contrast } \\
\hline & $\begin{array}{c}\text { Estimated } \\
\text { coefficients }\end{array}$ & $\begin{array}{c}\text { Marginal } \\
\text { effects }(\mathrm{dy} / \mathrm{dx})\end{array}$ & $\begin{array}{c}\text { Estimated } \\
\text { coefficients }\end{array}$ & $\begin{array}{c}\text { Marginal } \\
\text { effects }(\mathrm{dy} / \mathrm{dx})\end{array}$ \\
\hline Constant & $\begin{array}{c}11.0703 * * \\
(4.7914)\end{array}$ & 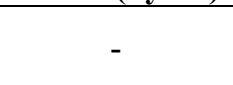 & $\begin{array}{c}-11.4186^{* * *} \\
(4.7598)\end{array}$ & 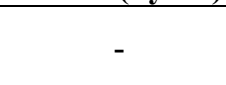 \\
\hline AGE & $\begin{array}{c}0.0192 \\
(0.0331)\end{array}$ & $\begin{array}{c}0.0017 \\
(0.0076)\end{array}$ & $\begin{array}{c}0.0455 \\
(0.0386)\end{array}$ & $\begin{array}{c}0.0041 \\
(0.0043)\end{array}$ \\
\hline EDU & $\begin{array}{l}-0.1415^{*} \\
(0.0749)\end{array}$ & $\begin{array}{l}-0.0482 \\
(0.0179)\end{array}$ & $\begin{array}{l}0.1862^{*} \\
(0.1035)\end{array}$ & $\begin{array}{c}0.0321 \\
(0.0130)\end{array}$ \\
\hline EXP & $\begin{array}{l}-0.0180 \\
(0.0343)\end{array}$ & $\begin{array}{l}-0.0006 \\
(0.0079)\end{array}$ & $\begin{array}{l}-0.0568 \\
(0.0449)\end{array}$ & $\begin{array}{l}-0.0056 \\
(0.0051)\end{array}$ \\
\hline HНM & $\begin{array}{c}-0.2926^{* * *} \\
(0.1488)\end{array}$ & $\begin{array}{l}-0.0773 \\
(0.0349)\end{array}$ & $\begin{array}{c}0.0605 \\
(0.1650)\end{array}$ & $\begin{array}{c}0.0274 \\
(0.0188)\end{array}$ \\
\hline DEO & $\begin{array}{c}0.0187 \\
(0.0374)\end{array}$ & $\begin{array}{c}0.0034 \\
(0.0088)\end{array}$ & $\begin{array}{c}0.0186 \\
(0.0455)\end{array}$ & $\begin{array}{c}0.0009 \\
(0.0052)\end{array}$ \\
\hline DFM & $\begin{array}{c}0.0241 \\
(0.0226)\end{array}$ & $\begin{array}{c}0.0137 \\
(0.0052)\end{array}$ & $\begin{array}{c}-0.1117 * * * \\
(0.0316)\end{array}$ & $\begin{array}{l}-0.0150 \\
(0.0038)\end{array}$ \\
\hline AMP & $\begin{array}{l}-0.4129 \\
(0.4395)\end{array}$ & $\begin{array}{l}-0.2519 \\
(0.0928)\end{array}$ & $\begin{array}{c}1.8632 * * * \\
(0.5941)\end{array}$ & $\begin{array}{c}0.3083 \\
(0.0949)\end{array}$ \\
\hline RQR & $\begin{array}{c}-0.5814^{* *} \\
(0.2796)\end{array}$ & $\begin{array}{l}-0.1909 \\
(0.0653)\end{array}$ & $\begin{array}{l}0.6603^{*} \\
(0.3604)\end{array}$ & $\begin{array}{c}0.1192 \\
(0.0437)\end{array}$ \\
\hline HPQ & $\begin{array}{l}0.1356^{*} \\
(0.0712)\end{array}$ & $\begin{array}{c}0.0535 \\
(0.0174)\end{array}$ & $\begin{array}{c}-0.2839 * * \\
(0.1165)\end{array}$ & $\begin{array}{l}-0.0433 \\
(0.0133)\end{array}$ \\
\hline PP & $\begin{array}{l}-0.0077 \\
(0.0058)\end{array}$ & $\begin{array}{l}-0.0027 \\
(0.0014)\end{array}$ & $\begin{array}{l}0.0111 * * \\
(0.0052)\end{array}$ & $\begin{array}{c}0.0019 \\
(0.0008)\end{array}$ \\
\hline FL & $\begin{array}{c}-0.5010^{*} \\
(0.2957)\end{array}$ & $\begin{array}{l}-0.2077 \\
(0.0712)\end{array}$ & $\begin{array}{c}1.1945 * * * \\
(0.4246)\end{array}$ & $\begin{array}{c}0.1776 \\
(0.0494)\end{array}$ \\
\hline TS & $\begin{array}{c}-0.9994 * * * \\
(0.3752)\end{array}$ & $\begin{array}{l}-0.1473 \\
(0.0947)\end{array}$ & $\begin{array}{c}-1.4864 * * * \\
(0.5087)\end{array}$ & $\begin{array}{l}-0.1090 \\
(0.0631)\end{array}$ \\
\hline
\end{tabular}

Note. Reference category: Millers; $* * *, * * \& *$ indicated significant at $1 \%, 5 \%$, and $10 \%$ respectively; in the parentheses were value of SE

Distance from farm to the main market (DFM): had a negative sign as expected and significant was at $1 \%$ level. It 
reduced the probability that a farmer sold to a trader relative to a miller by marginal effect about $1.50 \%$ if one kilometer addition. This could be explained that long-distance from the main market made smallholder farmers got high transportation costs, and spent time so that they increased the probability sold to closer markets as the indirect marketing channels.

Access to marketing price information (AMP): was a positive sign as expected and significant at $1 \%$ level. It increased probability which a farmer sold to a trader by marginal effect about $30.83 \%$ relative to a miller. Smallholder farmers used marketing price information were more likely to sell to direct marketing channels because they might have appropriate decisions of selling their products for increasing profitability. This result was consistent with Mmbando et al. (2016) found that smallholder farmers used marketing price information have significant positive and increased probability to maize producers sold to direct marketing channels.

Road quality from farm to the main road (RQR): had a negative and a positive sign as expected with significant at $5 \%$ and $10 \%$ level. It reduced the probability that a farmer sold to a collector relative to a miller by marginal about $19.09 \%$ if enhanced road quality one unit. On another hand, increased the probability that a farmer sold to a trader was a direct marketing channel by marginal effect about $11.92 \%$. Due to the good infrastructure of the road so that smallholder farmers were more likely to sell their products to direct marketing channels.

Household's product quantity (HPQ): had a positive and a negative sign as expected with significant at 10\% and 5\% level. It increased the probability to a farmer sold to a collector relative to a miller by marginal effect about $5.35 \%$ if increased one ton. On another hand, decreased the probability to a farmer sold to a trader was a direct marketing channel by marginal effect about $4.33 \%$. This illustrated that, smallholder farmers with large volumes of products sold to indirect marketing channels increased due to they might challenge with high transportation costs, lack transportations, and lack of storage items.

Product price (PP): had a positive sign as expected and significant was at $5 \%$ level. It increased the probability that a farmer selected a trader relative to a miller. Due to price increased in the market, it stimulated smallholder farmers sold to direct marketing channels for increasing their profits. This result was consistent with Gelaw et al. (2016) illustrated that price was one of the most vital factors to select the end-user.

Farming land (FL): had a negative and a positive sign as expected with significant at $10 \%$ and $1 \%$ level. The probability that a farmer sold to a collector decreased and a trader increased by marginal effect about $20.77 \%$ and $17.76 \%$ respectively if one hectare increased relative to a miller. Smallholder farmers had large of FL sold their products to millers more than collectors and sold to traders more than millers. It was a determinant factor indicative of production volumes and quantity for sale. Moreover, increasing cultivation urged to increase ratio of products that were available for direct marketing channels and greater willingness to sell to increasing profits.

Type of seed (TS): had both negatives sign as expected and each significant at $1 \%$ level. It reduced the probability that a farmer sold to a collector and a trader by marginal effect about $14.73 \%$ and $10.90 \%$ respectively relative to a miller. If smallholder farmers who cultivated early switched to medium or late rice, they would sell to millers increased relative to collectors and traders because traders tended to buy early rice for exportation but medium and late rice tended to sell to millers (Table 3). Therefore, type of seed was a determinant factor and reduce marketing channel choice.

\section{Conclusions and Policy Implications}

Empirical results revealed that the level of socio-economic, institutional, and marketing factors were statistically significant effects in the marketing channel choices by smallholder farmers sold their paddy products in both seasons. The findings of this study relate to the factors that need to resolve and stimulate smallholder farmers to choose the right marketing channels by suggestion to policymakers.

The household head's characteristics significantly influenced the marketing channels such as household head's age, farming experience, household head's education. Older smallholder farmers, smallholder farmers who had low farming experiences, and low education levels sold their products to indirect marketing channels. The outcome of policies needs to stimulate and encourage the extension office to support older farmers such as sharing information, technical, and relationship with direct buyers. Smallholder farmers who had low farming experience levels need to increase cultivations, relationships with buyers, and their involvement in the marketing channels. Whereas, smallholder farmers who had low education levels need to be invested in relevant marketing knowledge and skills through available training programs that can be offered by the extension services.

The results also illustrated that institutional factors significantly influenced smallholder farmers' decision to choose marketing channels such as distance from home to the extension office, access to marketing price information, and road quality from farm to the main road. Smallholder farmers who located in remote areas far 
from the extension office and poor access to marketing price information sold products to indirect marketing channel. The policymakers should increase and improve the extension office to near smallholder farmers by the focus on telecommunications with integrating ICT in agriculture, for instance, app of agricultural commodities price marketing update information. Whereas, smallholder farmers who located in poor road conditions and also used indirect marketing channels, they need to improve by providing the best priority to enhance the rural infrastructures such as roads, transportations, and so forth to reduce these barriers.

The factors of the household member, distance from farm to the main market, and household's product quantity also significantly influenced the marketing channels. Smallholder farmers who had large members increased likelihood sold their products to direct marketing channel because of large members were high labor that might urge high productivity and more relationships with buyers. Smallholder farmers who located far from the main market were more likely to sell to indirect marketing channels due to they might challenge with high transportation costs, spent time, and lack own transportations. Whereas, smallholder farmers with large volumes of products were more likely to sell to indirect marketing channels due to they might lack own transportations and storage items. Policies, smallholder farmers who located far from the main market and large volumes of products need to improve their own transportations and storage facilities for reducing these constraints.

This study further indicated that product price also significantly influenced smallholder farmers choosing the marketing channels in both seasons. If prices increased in the market, smallholder farmers were more likely would sell to direct marketing channels. So, high prices pointed out a vital factor urged smallholder farmers to increase production and used the direct marketing channels for selling their products. The outcome of policies needs to stimulate smallholder farmers to market participation, enhance the integration of smallholder farmers to markets, and work efforts to improve market competitions of private sector for increasing prices in the market.

Finally, the results also revealed that farming land and type of seed were important significantly influence on the marketing channels. Farming land increased likelihood into direct marketing channels in both seasons. It was a determinant factor indicative of production volumes and quantity for sale. In addition, increased farming size urged to increase the proportion of agricultural products that were available for direct marketing channels and greater willingness to sell for increasing the profits. Whereas, type of seed also increased likelihood into millers in both seasons due to smallholder farmers who produced medium and late rice tended to millers for increasing profits. Moreover, the millers bought medium and late rice by generated to milled rice products for local domestic consumption of household food and exportation, but early rice tended to sell to traders. Therefore, type of seed was a determinant factor and reduce marketing channel choice. Smallholder farmers produced mostly medium and early rice (medium $>$ early $>$ late rice) in the wet season due to the extent of irrigation systems might be large, but the volumes of late rice were small due to it might be spent time, high production cost, and high threatens. In the dry season, they produced mostly early and medium rice (early $>$ medium $>$ late rice) due to the water supply might be insufficient. The policymakers should work efforts to improve and enhance the ongoing investments in the water supporting such as small, medium, large irrigation systems, and so forth for increasing cultivations and switch cultivating from early to medium or late rice.

\section{Acknowledgements}

This research would not have been possible if without the supporting of the Center for International Agricultural Research (CIAR) of Chinese Academy of Agricultural Sciences (CAAS). The authors also acknowledge with gratitude to Leangheng Huth and Krem Siek for their constant cooperation in data collections in Prey Veng Province of Cambodia.

\section{References}

Abebe, G. K., Bijman, J., \& Royer, A. (2016). Are middlemen facilitators or barriers to improve smallholders' welfare in rural economies? Empirical evidence from Ethiopia. Journal of Rural Studies, 43, 203-213. https://doi.org/10.1016/j.jrurstud.2015.12.004

Adanacioglu, H. (2017). Factors affecting farmers' decisions to participate in direct marketing: A case study of cherry growers in the Kemalpasa District of Izmir, Turkey. Renewable Agriculture and Food Systems, 32(4), 291-305. https://doi.org/10.1017/S1742170516000193

Amaya, N., \& Alwang, J. (2011). Access to information and farmer's market choice: The case of potato in highland Bolivia. Journal of Agriculture, Food Systems, and Community Development, 1(4), 35-53. https://doi.org/10.5304/jafscd.2011.014.003

Arinloye, D.-D. A., Pascucci, S., Linnemann, A. R., Coulibaly, O. N., Hagelaar, G., \& Omta, O. S. (2014). Marketing Channel Selection by Smallholder Farmers. Journal of Food Products Marketing, 21(4), 
337-357. https://doi.org/10.1080/10454446.2013.856052

ASPIRE. (2019). Agriculture Policy Research Study "Modernizing agriculture sector: Long-term vision and policy orientation". Report on Agriculture Policy Research Study, MAFF: Phnom Penh, Cambodia. Retrieved from http://aspirekh.org/wp-content/uploads/2019/03/Report_on_Modernizing_Agriculture.pdf

Azam, M. S., Imai, K., \& Gaiha, R. (2012). Agricultural Supply Response and Smallholders Market Participation: the Case of Cambodia. EDP-1208, The University of Manchester: Manchester M13 9PL, UK. Retrieved from http://hummedia.manchester.ac.uk/schools/soss/economics/discussionpapers/EDP-1208.pdf

Baines, P., Fill, C., \& Rosengren, S. (2017). Marketing (4th ed.). Oxford: Oxford University Press, UK.

Balsevich, F., Schuetz, P., \& Perez, E. (2006). Cattle Producers' Participation in Market Channels in Central America: Supermarkets, Processors, and Auctions. Staff Paper. Retrieved from https://cgspace.cgiar.org/handle/10568/1734

Brumfield, R. G. (2005). A workbook for selecting market options and strategies for agricultural products (2nd ed.). New Jersey: Agricultural Experiment Station, USA. Retrieved from http://farmmgmt.rutgers.edu/marketing/tomarket.pdf

Bywaters, D., \& Mlodkowsk, P. (2012). The Role of Transactions Costs in Economic Growth. International Journal of Economic Policy Studies, 7, 53-66. https://doi.org/10.1007/BF03405737

Carter-Hill, R, Griffiths, W. E., \& Lim, G. C. (2008). Principles of Econometrics (3rd ed.). Hoboken, NJ: John Wiley \& Sons Inc, USA.

Cazzuffi, C., \& McKay, A. (2012). Rice market participation and channels of sale in rural Vietnam. International Association of Agricultural Economists (IAAE) Triennial Conference. Retrieved from $\mathrm{https}$ ///ageconsearch.umn.edu/bitstream/126566/2/Cazzuffi-McKay_IAAE_17128.pdf

Council for the Development of Cambodia. (2014). Municipality and Province Investment Information in Prey Veng Province. Investment Information Report, CDC : Phnom Penh, Cambodia. Retrieved from http://www.cambodiainvestment.gov.kh/wp-content/uploads/2014/03/Prey-Veng-Province_eng.pdf

De Bruyn, P., De Bruyn, J. N., Vink, N., \& Kirsten, J. F. (2001). How transaction costs influence cattle marketing decisions in the northern communal areas of Namibia. Agrekon, 40(3), 405-425. https://doi.org/10.1080/03031853.2001.9524961

EuroCham Cambodia. (2018). Agriculture in Cambodia. Retrieved from www.netherlandsworldwide.nl/binaries/en-nederlandwereldwijd/documents/publications/2018/10/04/agricu lture-in-cambodia/Agriculture+in+Cambodia.pdf

Fafchamps, M., \& Hill, R. V. (2005). Selling at the farm gate or traveling to market. American Journal of Agricultural Economics, 87(3), 717-734. https://doi.org/10.1111/j.1467-8276.2005.00758.x

Farmer, J. R., \& Betz, M. E. (2016). Rebuilding local foods in Appalachia: Variables affecting distribution methods of West Virginia farms. Journal of Rural Studies, 45, 34-42. https://doi.org/10.1016/j.jrurstud.2016.03.002

Gelaw, F., Speelman, S., \& Van Huylenbroeck, G. (2016). Farmers' marketing preferences in local coffee markets: Evidence from a choice experiment in Ethiopia. Food Policy, 61, 92-102. https://doi.org/10.1016/j.foodpol.2016.02.006

Getahun, K., Eskinder, Y., \& Desalegn, A. (2017). Determinants of smallholder market participation among banana growers in bench Maji Zone, Southwest Ethiopia. International Journal of Agricultural Policy and Research, 5(11), 169-177. https://doi.org/10.15739/IJAPR.17.020

Girma, M., \& Abebaw, D. (2012). Patterns and determinants of livestock farmers' choice of marketing channels: micro-level evidence. Working Paper, Adama University: Adama, Ethiopia. Retrieved from https://www.africaportal.org/documents/16464/WP_1_2012_Mamo_Girume_and_Degnet_Abebaw_2.pd $\mathrm{f}$

Greene, W. H. (2003). Econometric analysis (5th ed.). Upper Saddle River, New Jersey: Prentice Hall, USA.

Gujarati, D. N., \& Porter, D. C. (2009). Basic econometrics (5th ed.). New York: McGraw-Hill/Irwin, USA.

Higuchi, A., Moritaka, M., \& Fukuda, S. (2012). The Impact of Socio-Economic Characteristics on Coffee Farmers' Marketing Channel Choice: Evidence from Villa Rica, Peru. Sustainable Agriculture Research, 1, 13-18. https://dx.doi.org/10.5539/sar.v1n1p13 
Jari, B. (2009). Institutional and Technical Factors Influencing Agricultural Marketing Channel Choices amongst Smallholder and Emerging Farmers in the Kat River Valley (Unpublished master's thesis). University of Fort Hare, Alice, South Africa.

Jari, B., \& Fraser, G. C. G. (2009). An analysis of institutional and technical factors influencing agricultural marketing amongst smallholder farmers in the Kat River Valley, Eastern Cape Province, South Africa. African Journal of Agricultural Research, 4(11), 1129-1137. Retrieved from https://pdfs.semanticscholar.org/0654/d9042a02e7ec9ca4c632808c01fdc43d87c8.pdf

Kea, S., Li, H., \& Pich, L. (2017). Comparison of Cambodian Rice Production Technical Efficiency at National and Household Level. Preprints, 1-27. https://doi.org/10.20944/preprints201709.0161.v1

Kyaw, N. N., Ahn, S., \& Lee, S. H. (2018). Analysis of the Factors Influencing Market Participation among Smallholder Rice Farmers in Magway Region, Central Dry Zone of Myanmar. Sustainability, 10, 4441. https://doi.org/10.3390/su10124441

LeRoux, M. (2010). Guide to Marketing Channel Selection: How to Sell Through Wholesale and Direct Marketing Channels. Cornell Cooperative Extension of Tompkins County: South Central NY, USA. Retrieved from http://cceoneida.com/resources/guide-to-marketing-channels

MacInnis, B. (2004). Transaction costs and organic marketing: evidence from US organic produce farmers. American Agricultural Economics Association (AAEA), 1-4. https://doi.org/10.22004/ag.econ.20386

Maina, C. M., Lagat, J. K., \& Mutai, B. K. (2015). Effect of transaction costs on choice of mango marketing channel: the case of small scale farmers in Makueni County, Kenya. Journal of Agriculture and Veterinary Science (IOSR-JAVS), $8(4), \quad 54-62 . \quad$ Retrieved from https://pdfs.semanticscholar.org/abc3/00ab18d4c09ad21a8ed60555ea11e7e753ec.pdf

McFadden, D. (1986). The Choice Theory Approach to Market Research. Marketing Science, 5(4), 275-297. https://doi.org/10.1287/mksc.5.4.275

Ministry of Agriculture Forestry and Fisheries [MAFF]. (2018). Annual report for agriculture forestry and fisheries 2017-2018 and direction 2018-2019. MAFF conference, MAFF: Phnom Penh, Cambodia. Retrieved from http://oads.or.kr/upload_file/bbs/56-1.MAFF-2017-2018\%20(EN)-Final-Binder.pdf

Ministry of Planning. (2019). General population census of the kingdom Cambodia 2019. Provisional Population Totals, MoP: Phnom Penh, Cambodia. Retrieved from http://www.nis.gov.kh/nis/Census2019/Provisional\%20Population\%20Census\%202019_English_FINAL.pd $\mathrm{f}$

Mmbando, F. E., Wale, E., Baiyegunhi, L. J. S., \& Darroch, M. A. G. (2016). The Choice of Marketing Channel by Maize and Pigeonpea Smallholder Farmers: Evidence from the Northern and Eastern Zones of Tanzania. Agrekon, 55(3), 254-277. https://doi.org/10.1080/03031853.2016.1203803

Monson, J., Mainville, D., \& Kuminoff, N. (2008). The Decision to Direct Market: An Analysis of Small Fruit and Specialty-Product Markets in Virginia. Journal of Food Distribution Research, 39(2), 1-11. Retrieved from https://core.ac.uk/download/pdf/6407374.pdf

Mutura, J. K., Nyairo, N., Mwangi, M., \& Wambugu, S. K. (2015). Analysis of determinants of market channel choice among smallholder dairy farmers in Lower Central Kenya. International Journal Innovation research and Development, 4, 1-12. Retrieved from https://pdfs.semanticscholar.org/be48/bed77e595a9c714c4dd6b6a520e019ab82ca.pdf

Omamo, S. W. (1998). Transport costs and smallholder cropping choices: An application to Siaya District, Kenya. American Journal of Agricultural Economics, 80(1), 116-123. https://doi.org/10.2307/3180274

Ouma, E., Jagwe, J., Obare, G., \& Abele, S. (2010). Determinants of smallholder farmers' participation in banana markets in Central Africa: The role of transaction costs. Agricultural Economists, 41(2), 111-122. https://doi.org/10.1111/j.1574-0862.2009.00429.x

Renos, V., Sadoulet, E., \& De Janvry, A. (2003). Measuring transactions costs from observed behavior: Market choices in Peru. Retrieved from https://gspp.berkeley.edu/assets/uploads/research/pdf/TC-wp.pdf

Seemanon, K., Sanguanwongse, V., Titapiwatanakun, B., Sirisupluxana, P., Kikuchi, P., \& Yamao, M. (2015). Preparing agricultural product marketing for the new AEC market: A case study for improving the marketing organization for farmers in Chiang Rai Province, Thailand. Journal of Agricultural Extension and Rural Development (JAERD), 7(4), 105-113. https://doi.org/10.5897/JAERD2014.0658 
Shephard, S., Kefasi, N., Aliou, D., Fatunbi, A. O., \& Adekunle, A. A. (2011). Determinants of cereal market participation by sub-Saharan Africa smallholder farmers. Journal of Agriculture and Environmental Studies, 2(1), 180-193.

Shiimi, T., Taljaard, P. R., \& Jordaan, H. (2012). Transaction costs and cattle farmers' choice of marketing channel in North-Central Namibia. Agrekon, 51(1), 42-58. https://doi.org/10.1080/03031853.2012.649543

Soe, W. P. P., Moritaka, M., \& Fukuda, S. (2015). An Analysis of the Factors Influencing Marketing Channel Choice by Paddy Rice Farmers in Myanmar. Journal-Faculty of Agriculture Kyushu University, 60(2), 535-542. $\quad$ Retrieved from https://pdfs.semanticscholar.org/21a1/4d3c5fc55b1ce59db477b5f2f721a7cef258.pdf

Strauss, J., Barbosa, M., Teixeira, S., Thomas, D., \& Raimundo, G. J. (1991). Role of education and extension in the adoption of technology: A study of upland rice and soybean farmers in Central-West Brazil. Agricultural $\begin{array}{lllll}\text { Economics, } & 5, & \text { 341-359. } & \text { Retrieved }\end{array}$ https://ageconsearch.umn.edu/bitstream/172778/2/agec1991v005i004a003.pdf

Tsourgiannis, L., Eddison, J., \& Warren, M. (2008). Factors affecting the marketing channel choice of sheep and goat farmers in the region of east Macedonia in Greece regarding the distribution of their milk production. Small Ruminant Research, 79(1), 87-97. https://doi.org/10.1016/j.smallrumres.2008.07.005

Waqar, M., Gu, R., \& Nie, F. (2018). Mapping ICT Use along the Citrus (Kinnow) Value Chain in Sargodha District, Pakistan. Sustainability, 10, 4743. https://doi.org/10.3390/su10124743

World Bank. (2019). Cambodia economic update. Recent economic developments and outlook, World Bank Group: Phnom Penh, Cambodia. Retrieved http://documents.worldbank.org/curated/en/843251556908260855/pdf/Cambodia-Economic-Update-Recent -Economic-Developments-and-Outlook.pdf

Zivenge, E., \& Karavina, C. (2012). Analysis of factors influencing market channel access by communal horticulture farmers in Chinamora District, Zimbabwe. Journal of Development and Agricultural Economics, $\quad 4(6), \quad 147-150 . \quad$ Retrieved from http://www.academicjournals.org/app/webroot/article/article1379963180_Zivenge and Karavina.pdf

\section{Copyrights}

Copyright for this article is retained by the author(s), with first publication rights granted to the journal.

This is an open-access article distributed under the terms and conditions of the Creative Commons Attribution license (http://creativecommons.org/licenses/by/4.0/). 